\title{
DISTRIBUTION OF LINDANE IN WATER, SEDIMENT, AND FISH FROM THE WARRI RIVER OF THE NIGER DELTA, NIGERIA
}

\author{
Lawrence Ikechukwu EZEMONYE, Thomas Ohwofasa IKPESU, and Isioma TONGO \\ Department of Animal and Environmental Biology (AEB), University of Benin, Benin City, Nigeria
}

Received in August 2008

Accepted in October 2008

\begin{abstract}
This paper is the first attempt to quantify the levels and the distribution pattern of lindane in the surface water, sediment and fish (Chrysichthys furcatus and Tilapia zilli). The samples were collected from three stations (Ovwian, Ekakpamre, and Ovu) of the Warri River in the western Niger Delta of Nigeria in 2006: during the dry (January-April) and wet seasons (May-August). The analysis included a total of 96 samples made up of 24 samples each for water, sediment, and fish. The pesticide levels were analysed using high performance liquid chromatography to elucidate its distribution in various environmental compartments. Residue levels in the matrices ranged from below the detection limit (BDL) to $1.37 \mu \mathrm{g} \mathrm{L}^{-1}$ in water, BDL to $12.66 \mu \mathrm{g} \mathrm{g}^{-1}$ dry weight (dw) in sediment, BDL to $16.67 \mu \mathrm{g} \mathrm{g}^{-1} \mathrm{dw}$ in Chrysichthys furcatus, and BDL to $0.15 \mu \mathrm{g} \mathrm{g}^{-1} \mathrm{dw}$ in Tilapia zilli. The observed values were above the ecological benchmarks $\left(0.01 \mu \mathrm{g} \mathrm{L}^{-1}\right)$ recommended by the Nigerian Environmental Protection Agency and European Union. They were also relatively higher than in previous studies on the Nigerian environment, which calls for regular monitoring of the Niger Delta water bodies.
\end{abstract}

KEY WORDS: benchmarks, bioaccumulation, Chrysichthys furcatus, surface water, Tilapia zilli

The Warri River is a major navigable channel of the Niger Delta, southern Nigeria. It takes its origin from around Utagba Uno and flows through zones of freshwater swamps, mangrove swamps, and coastal sand ridges. It is a relatively large water body which stretches within latitudes $5^{\circ} 21^{\prime}-6^{\circ} 00^{\prime} \mathrm{N}$ and longitude $5^{\circ} 24^{\prime}-6^{\circ} 21^{\prime} \mathrm{E}$, covering a surface area of about $255 \mathrm{sq} \mathrm{km}$ with a length of about $150 \mathrm{~km}$ (1$3)$. It drains various tributaries and empties into the brackish Forcados that in turn empties into the Atlantic Ocean (Figure 1).

Lindane is an organochlorine pesticide, which is under a great deal of regulatory pressure around the world. The usage of lindane has been banned in many countries of the world (4). For example in Europe lindane use was reduced by two-thirds between 1970 and 1996, and was banned outright for plant protection in some European countries. The state of California has banned lindane-based products used in the treatment of lice and scabies (5). In Canada and other countries, lindane is generally not used to treat young children, and has voluntarily been withdrawn from the market $(6,7)$.

The pesticide is an immobile, long-lived insecticide widely examined in the scientific literature (8). Lindane is highly persistent in most soils, with a field half-life of approximately 15 months (9). When sprayed on the surface, the half-life was typically much shorter than when incorporated into the soil (10). It shows a low affinity for soil binding, and may be mobile in soils with especially low organic matter content or subject to high rainfall (9).

Lindane is a broad spectrum insecticide, which has been used since 1949 for agricultural and 


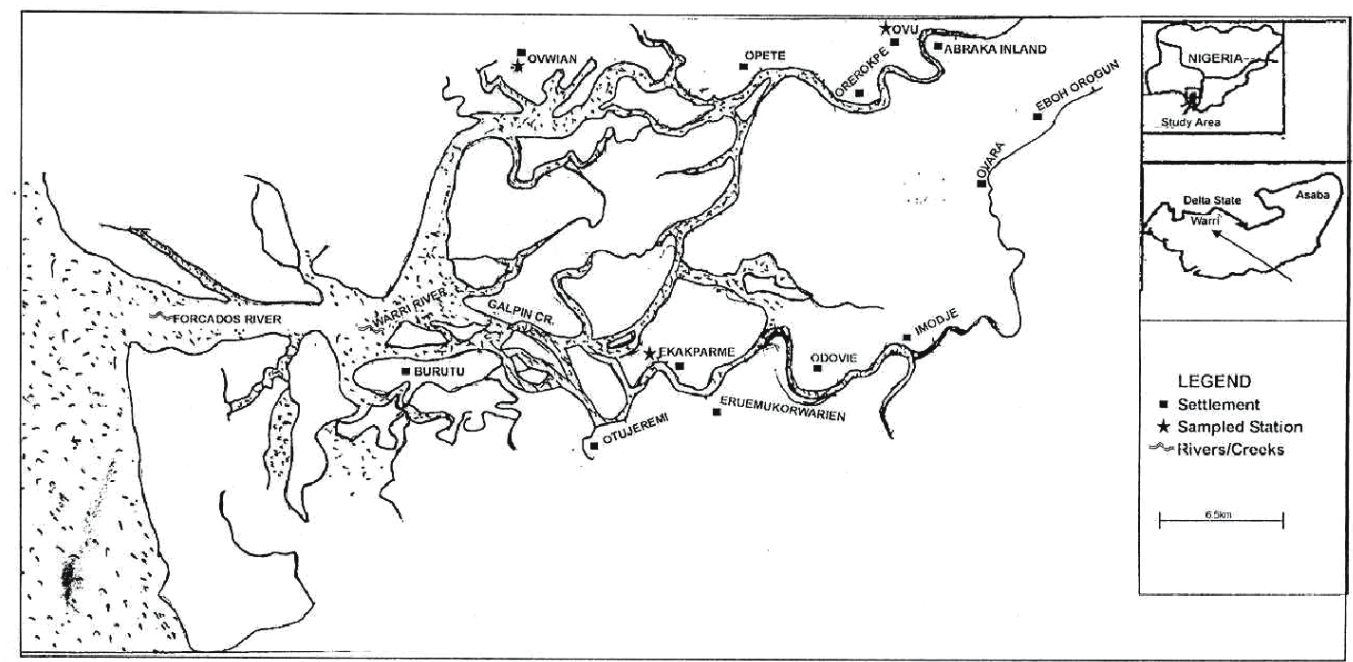

Figure 1 Map of the entire Warri River (Modified after Ezemonye, 2005). Source: Ministry of Land and Survey, Asaba, Nigeria.

non agricultural purposes. Major agricultural use include seed and soil treatment, and wood and timber protection (11). Lindane is also used against ectoparasites in veterinary and pharmaceutical products (12). As a pharmaceutical preparation, lindane is an insecticide, larvicide, and acaricide. It is used topically in concentrations of $1 \%$ for the treatment of scabies in some patients (13). It is administered differently to treat pediculosis. It is also used for the control of disease vectors, including mosquitoes, lice, and fleas (14).

The pesticide has a relatively high degree of accumulation in aquatic organisms and is highly toxic to mammals, with an acute oral $\mathrm{LD}_{50}$ in rats of $70 \mathrm{mg} \mathrm{kg}^{-1}$ (12). Soil conservation service rates lindane with an extra small potential for loss due to leaching, a large potential for loss due to surface adsorption, and a moderate potential for loss in surface solution (15).

The uncompromising demand of sustainable development is in the focus of cooperation between agricultural production and environmental protection. There is significant evidence that most agricultural chemicals have a long-term impact on the environment. (16). The use of agrochemicals has long been a prominent feature of conventional agricultural practices, and their use has made it possible to increase crop yield and food production. However, many of these chemicals have toxic effects that are not confined to their target species and environment (16).

Although the use of organochlorine pesticides such as lindane in agriculture was banned in Nigeria, it has continued for many years after. The chemical stability of these compounds, their high lipid solubility, and toxicity to humans and animals (17) have raised concern among governments and researchers about their presence in the environment. Currently, there is a widespread concern about the concentrations and effects of lindane on aquatic resources in the western Niger Delta (16). Ecotoxicological research on pesticides in Nigeria is in its infancy when compared with research in the parent fields of experimental ecology and toxicology (17).

Organochlorine water contamination pathways in the Warri River are likely to be nonpoint sources including runoff, atmospheric deposition, and leaching due to agricultural applications and vector control practices. Sediments can act as a sink for persistent contaminants, whose re-suspension at the sediment-water interface, especially in storm events and during River mixing, may increase pesticide bioavailability and accumulation in the food chain. The Warri River is a source of potable water, fish, and a place for recreation. Pesticide pollution is therefore likely to pose a threat to both aquatic organisms and humans. Generally, it is believed that contaminants taken in by aquatic organisms are from water, rather than from their food, and may vary with seasonal variation in contaminant availability within the water column (18). Fish act as nonpolar media that can adsorb hydrophobic organic chemicals within the water column. Since birds and humans consume fish, this makes fish good biomonitors for xenobiotic pollutants. The ingestion of foods contaminated with persistent lipophilic pesticides can result in the 
accumulation of these pesticides in humans. The potential for pesticide residues to cross the placental barrier (19), even if it were in trace concentrations, may cause serious damage in the newborns and therefore raises great concern. Organochlorine pesticides have already been implicated in a broad range of adverse human health and environmental effects, including reproductive failures and birth defects (20), immune system dysfunction, endocrine disruptions, and cancers $(10,20,21)$.

Researchers have detected pesticides residues in Nigerian water. The detected pesticides include diedrin, lindane, heptachlor, endosulfan, aldrin, DDT, and PCB. Many of these pesticides have also been detected in sediments, aquatic plants, and fish (17).

Until recently, the adverse effects of pesticides and their residues on non-target organisms have not been seriously considered in Nigeria. The use of pesticides is on increase to improve farming and fishing. This investigation was motivated by their spread and risks involved. There are no documented reports on residual levels of pesticides in the Western Niger Delta region. To the author's knowledge, this investigation is the first evaluation of pesticide concentrations in the water, sediment, and fish samples from the Warri River. Therefore, in addition to providing baseline information, this study will also provide a basis for ecological risk assessment of pesticide use in the Western Niger Delta and Nigeria in general.

\section{MATERIALS AND METHODS}

\section{Study area and sampling schedule}

The study area was the Warri River with stations established at Ekakpamre, Ovwian, and Ovu. Ekapamre and Ovwian stations were chosen to investigate possible sources of pesticide contamination. Catchments of intensive agricultural use drain into these stations. The third, upstream station Ovu served as control. The sampling stations were visited on a monthly basis to collect water, sediment, and fish samples for pesticide residue analysis.

Two dominant fish species were selected for this study; Chrysichthys furcatus and Tilapia zilli. These fish were chosen because they are the most common species eaten by many people in the region. We tried as much as possible to collect fish of similar size for each species for tissue analysis. Chrysichthys furcatus ranged from $60 \mathrm{~cm}$ to $75 \mathrm{~cm}$ in length while Tilapia zilli ranged from $36 \mathrm{~cm}$ to $55 \mathrm{~cm}$.

\section{Limnological parameters}

Water temperature, electrical conductivity, and $\mathrm{pH}$ were measured on site. Temperature and $\mathrm{pH}$ were measured using a calibrated Orion Model 250A pH meter, while electrical conductivity was measured using an Orion Model 122 conductivity meter (Thermo Electron Corp., Milford, MA).

\section{Collection of samples}

We collected 1-litre surface water grab samples from the centre of the flow at each station. The grab samples were collected every month, approximately thirty days apart, and kept refrigerated until analysis. Sediment samples were taken from where fine-texture substrates accumulated. The upper $2 \mathrm{~cm}$ of the bed sediment at each site were collected with a tefloncoated spoon and wrapped in aluminium foil (five samples of surface water and sediment from each station were collected for analysis). Samples were immediately placed on ice $(<6 \mathrm{~h})$ and then stored at $-20{ }^{\circ} \mathrm{C}$ in the laboratory until analysis. From each station, six samples each of Chrysichthys furcatus and Tilapia zilli were captured, weighing $2.5 \mathrm{~kg}$ and $1.2 \mathrm{~kg}$, respectively, wrapped in aluminium foil, and kept at $-20^{\circ} \mathrm{C}$ in the laboratory until analysis.

\section{Chemical Analysis}

Lindane (98.5\% purity) and methanol (analytical grade) for high-performance liquid chromatography (HPLC) were obtained from Chemical Service (West Chester, PA, USA). High purity pesticide grade solvents (hexane, dichloromethane and the surrogate standard solution) were obtained from Merck (Darmstadt, Germany). $\mathrm{Na}_{2} \mathrm{SO}_{4}$ (99\% purity), petroleum ether (analytical grade), and acetonitrile (analytical grade) were supplied by Sigma-Aldrich (USA) and helium (purity $99.999 \%$ ) by Messer Technogas (Czech Republic). Equipment included glassware, Cecil HPLC system comprised of CE 1200 high performance variable wavelength monitor and CEIIOO liquid chromatography pump, UV detector with variable wavelength and stainless steel column $\left(\mathrm{C}_{18}\right.$ Reverse phase) packed with Octasilica, vacuum pump, and ultrasonic check.

One-litre water samples were extracted using ultrasonic extraction. Soxhlet extraction was done with $20 \mathrm{~mL}$ of hexane:dichloromethane $(3: 1)$ for 30 minutes. The extract was concentrated using a rotary evaporator and eluted with HPLC methanol. 
Wet sediment samples were homogenised, air dried, and passed through a no. 32 mesh sieve. Fifteen grams of the sediment were spiked with a solution of surrogate standard (d8-naphthalene, d10-acenaphthene, d12-chrysene, and d12-perylene), and extracted with a mixture of dichloromethane and $n$-hexane in a ratio $2: 3$ after vigorous shaking in a sonication bath for 5 hours. The extraction solvent was evaporated to dryness using a rotary vacuum evaporator at $30^{\circ} \mathrm{C}$, and the evaporation residue was re-dissolved in $1 \mathrm{~mL}$ of hexane.

Lindane was extracted from fish samples according to the method described by Steinwadter (22). Each fish sample was examined separately, and 192 analyses were performed. Before the extraction, the bones were removed. A commercial meat chopper was used to macerate the fillet while still partially frozen, as this makes the skin more brittle. Each analysis required about $50 \mathrm{~g}$ of the edible part of the fish, which was then homogenised and macerated in a metallic blender at high speed with three consecutive volumes $(150 \mathrm{~mL}, 100 \mathrm{~mL}$, and $100 \mathrm{~mL}$ ) of petroleum ether. The extracts from each portion were combined in a 250 -mL volumetric flask and made up to volume. A portion ( $25 \mathrm{~mL}$ ) of the combined extract was used to determine the extractable fat content, while $200 \mathrm{~mL}$ was evaporated to near dryness on a rotary evaporator. The residue in the flask was then transferred with three 1-mL portions of acetonitrile-dichloromethane mixture $(25 / 75 \mathrm{v} / \mathrm{v})$ to a centrifuge tube and frozen for 24 hours. The frozen extract was centrifuged in a Heraeus Biofuge 22R centrifuge (Heraeus Instruments $\mathrm{GmbH}$, Germany), operated at $15000 \mathrm{rpm}$ and $0{ }^{\circ} \mathrm{C}$, to precipitate the fat. The supernatant was transferred to a weighed flask. The precipitation step was repeated and the supernatants were combined. The combined extract, equivalent to $20 \mathrm{~g}$ of fish tissue, was loaded onto a column of $20 \mathrm{~g}$ activated florisil. The florisil was topped with $4 \mathrm{~g}$ of anhydrous $\mathrm{Na}_{2} \mathrm{SO}_{4}$. The column was eluted with HPLC methanol.

\section{Preparation of standard stock solution}

One milligram of the standard per gram of stock solution was prepared by adding $0.1 \mathrm{~g}$ of lindane standard into a $100 \mathrm{~mL}$ volumetric flask. Five millilitres of methanol were then added to the volumetric flask to dissolve the standard. Distilled water was then used to fill the flask to the $100 \mathrm{~mL}$ mark.

\section{Activation of the HPLC system}

The target wavelength for the analyses was determined using UV-visible equipment. A small quantity of the stock solution was diluted with methanol, and its wavelength of $202 \mathrm{~nm}$ was determined by scanning. The instrument wavelength was then set at $202 \mathrm{~nm}$, with a sensitivity of $0.05 \mathrm{~nm}$ and a flow rate of $1 \mathrm{~mL} \mathrm{~min}^{-1}$. The instrument was purged to remove air and charge the column. Purging was conducted using a washing solution of $30 \%$ methanol and $70 \%$ distilled water.

\section{Degassing the mobile phase solution}

Helium gas was bubbled into the solution to degas the mobile phase. The mobile phase was then injected into the instrument and allowed to run through the system for 20 minutes. The system was then separated following the procedures outlined in the instrument operating manual.

\section{Determination of retention time for standard}

The lindane standard was injected into the chromatograph to determine the retention time. A series of concentrations ranging from $0.025 \mathrm{mg} \mathrm{L}^{-1}$ to $100 \mathrm{mg} \mathrm{L}^{-1}$ where then injected. The resulting peak areas were plotted against concentrations to determine the linearity of detector response to the standard. Using this approach, the retention time for the lindane standard was 4.21 minutes.

\section{Pesticide analysis}

Each sample residue (water, sediment, and fish) was dissolved in $1 \mathrm{~mL}$ of methanol. The extracted residue was then loaded and injected into the valve of the HPLC system. The resulting chromatogram for each sample was printed out. The retention times and concentrations were recorded.

\section{Data analysis}

The data were summarised separately for each sampling station using descriptive statistics (means, range, and histogram). The Student's $t$-test and analysis of variance (ANOVA) were used to test for significance at the 0.05 level of probability for the seasons and the stations, respectively.

\section{RESULTS}

Results of spatial and seasonal variations in lindane levels in the surface water, sediment, and fish $(C$. furcatus and T. zilli) from the Warri River are shown in Tables 1 and 2 with further illustrations in Figures 2-5. 
Table 1 Lindane levels during the dry season in (a) surface water, (b) fine-particle sediments, and (c) fish species at three sites along the Warri River, sampled monthly from January to April 2006. The means are based on monthly measurements. ND=Not detectable

\begin{tabular}{|c|c|c|c|c|c|c|c|c|c|c|c|c|}
\hline & \multicolumn{3}{|c|}{ Surface water $/ \mu \mathrm{g} \mathrm{L}^{-1}$} & \multicolumn{3}{|c|}{ Sediment $/ \mu g g^{-1} d w$} & \multicolumn{3}{|c|}{ Chrysichthys furcatus / $\mu \mathrm{g} \mathrm{g}^{-1} \mathrm{dw}$} & \multicolumn{3}{|c|}{ Tilapia zilli / $\mu \mathrm{g} \mathrm{g} \mathrm{g}^{-1} \mathrm{dw}$} \\
\hline & Mean $\pm S D$ & SE & RANGE & Mean \pm SD & SE & RANGE & Mean $\pm S D$ & SE & RANGE & Mean \pm SD & SE & RANGE \\
\hline $\begin{array}{l}\text { Ovwian } \\
\text { station }\end{array}$ & $0.76 \pm 024$ & 0.1180 & $0.49-1.05$ & $9.19 \pm 5.19$ & 2.597 & ND-12.66 & $2.50 \pm 0.02$ & 0.01 & $1.01-5.34$ & ND & & \\
\hline $\begin{array}{l}\text { Ekakpamre } \\
\text { station }\end{array}$ & $0.24 \pm 0.21$ & 0.1035 & $0.09-0.47$ & $3.54 \pm 2.91$ & 1.453 & ND-7.41 & $0.29 \pm 0.02$ & 0.1025 & $0.01-1.03$ & ND & & \\
\hline $\begin{array}{l}\text { Ovu station } \\
\text { (control) }\end{array}$ & $0.07 \pm 0.03$ & 0.0140 & $0.05-0.09$ & $0.47 \pm 0.42$ & 0.2115 & ND-0.92 & $0.02 \pm 0.06$ & 0.03 & ND-0.05 & ND & & \\
\hline
\end{tabular}

Table 2 Lindane levels during the wet season in (a) surface water, (b) fine-particle sediments, and (c) fish species at three sites along the Warri River, sampled monthly from May to August, 2006. The means are based on monthly measurements. ND=Not detectable.

\begin{tabular}{|c|c|c|c|c|c|c|c|c|c|c|c|c|}
\hline & \multicolumn{3}{|c|}{ Surface water $/ \mu \mathrm{g} \mathrm{L}^{-1}$} & \multicolumn{3}{|c|}{ Sediment $/ \mu g g^{-1} d w$} & \multicolumn{3}{|c|}{ Chrysichthys furcatus / $\mu \mathrm{g} \mathrm{g}^{-1} \mathrm{dw}$} & \multicolumn{3}{|c|}{ Tilapia zilli / $\mu \mathrm{g} \mathrm{g}^{-1} \mathrm{dw}$} \\
\hline & Mean $\pm S D$ & SE & RANGE & Mean $\pm S D$ & SE & RANGE & Mean \pm SD & SE & RANGE & Mean \pm SD & SE & RANGE \\
\hline $\begin{array}{l}\text { Owwian } \\
\text { station }\end{array}$ & $0.61 \pm 0.71$ & 0.354 & $0.01-1.37$ & $2.29 \pm 2.31$ & 1.153 & $0.30-5.60$ & $12.09 \pm 0.87$ & 0.437 & $5.34-16.67$ & $0.10 \pm 0.49$ & 0.0126 & $0.06-0.15$ \\
\hline $\begin{array}{l}\text { Ekakpamre } \\
\text { station }\end{array}$ & $0.21 \pm 0.17$ & 0.084 & $0.1-0.40$ & $1.28 \pm 1.90$ & 0.9475 & $0.01-4.01$ & $6.61 \pm 0.39$ & 0.1955 & $3.22-10.09$ & $0.02 \pm 0.02$ & 0.0114 & $0.01-0.04$ \\
\hline $\begin{array}{l}\text { Ovu station } \\
\text { (control) }\end{array}$ & $\mathrm{ND}$ & & & $0.24 \pm 0.32$ & 0.1575 & $0.02-0.46$ & $0.38 \pm 0.63$ & 0.3075 & $0.09-0.96$ & ND & & \\
\hline
\end{tabular}

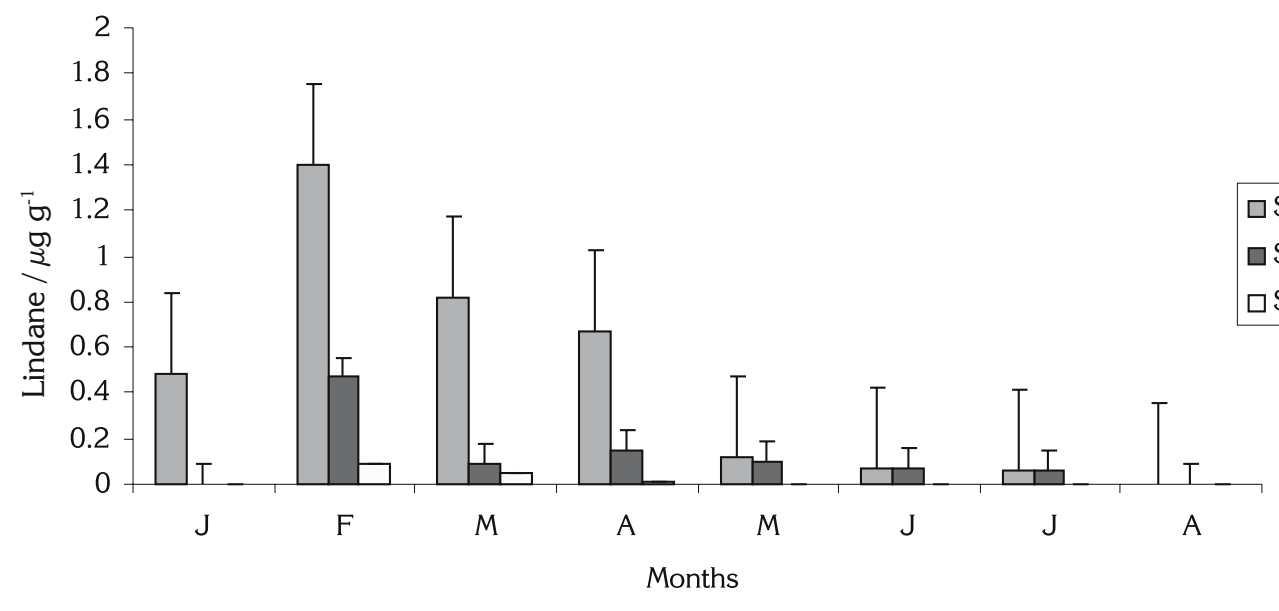

Figure 2 Lindane concentrations $\left(\mu \mathrm{g} \mathrm{L}^{-1}\right)$ in surface water of the Warri River, Niger Delta, Nigeria. Data are presented as monthly concentration \pm standard error.

Lindane in surface water

Mean lindane concentrations in the surface water were $0.69 \mu \mathrm{g} \mathrm{L}^{-1}$ at Ovwian, $0.25 \mu \mathrm{g} \mathrm{L}^{-1}$ at Ekakpamre, and $0.05 \mu \mathrm{g} \mathrm{L}^{-1}$ at Ovu, while the respective mean value for dry and wet seasons were $0.76 \mu \mathrm{g} \mathrm{L}^{-1}$ and
$0.61 \mu \mathrm{g} \mathrm{L}^{-1}$ at Ovwian, $0.24 \mu \mathrm{g} \mathrm{L}^{-1}$ and $0.21 \mu \mathrm{g} \mathrm{L}^{-1}$ at Ekakpamre, and $0.07 \mu \mathrm{g} \mathrm{L}^{-1}$ and not detected (ND) at Ovu (Tables 1 and 2). The detection limit was $0.01 \mu \mathrm{g} \mathrm{L}^{-1}$. These results indicate that pesticide concentrations are significantly different in both time and space at the level of $\mathrm{p}<0.05(\mathrm{~F}=7.61)$. 


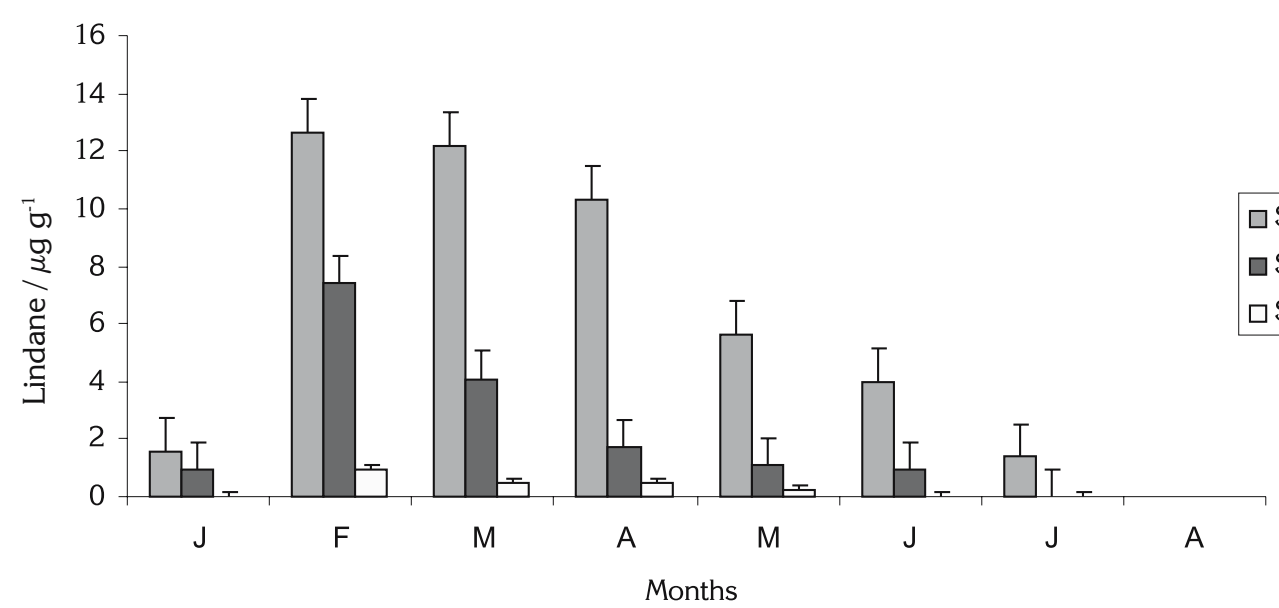

Figure 3 Lindane mass fractions in sediment $\left(\mu \mathrm{g} \mathrm{g}^{1} \mathrm{dw}\right.$ ) of the Warri River, Niger Delta, Nigeria. Data are presented as monthly mass fraction \pm standard error.

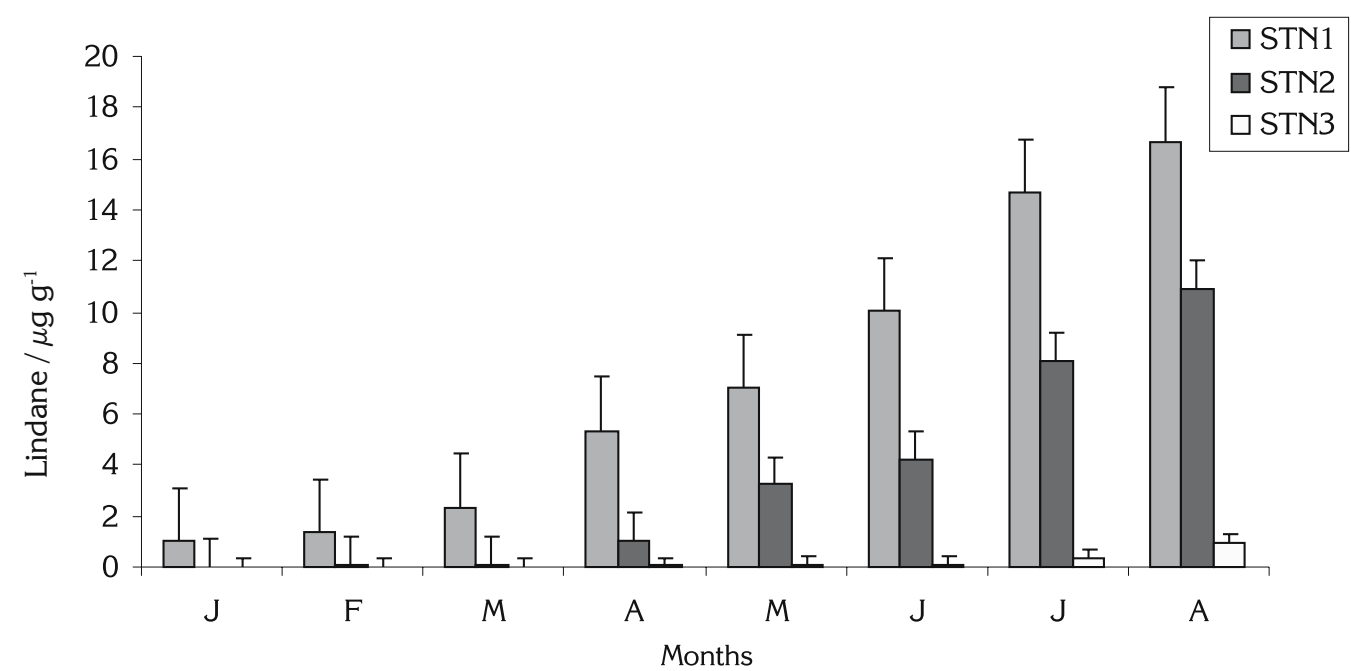

Figure 4 Lindane mass fractions $\left(\mu \mathrm{g} \mathrm{g}^{1} \mathrm{dw}\right)$ in fatty tissue of Chrysichths furcatus captured in the Warri River, Niger Delta, Nigeria. Data are presented as monthly mass fraction \pm standard error.

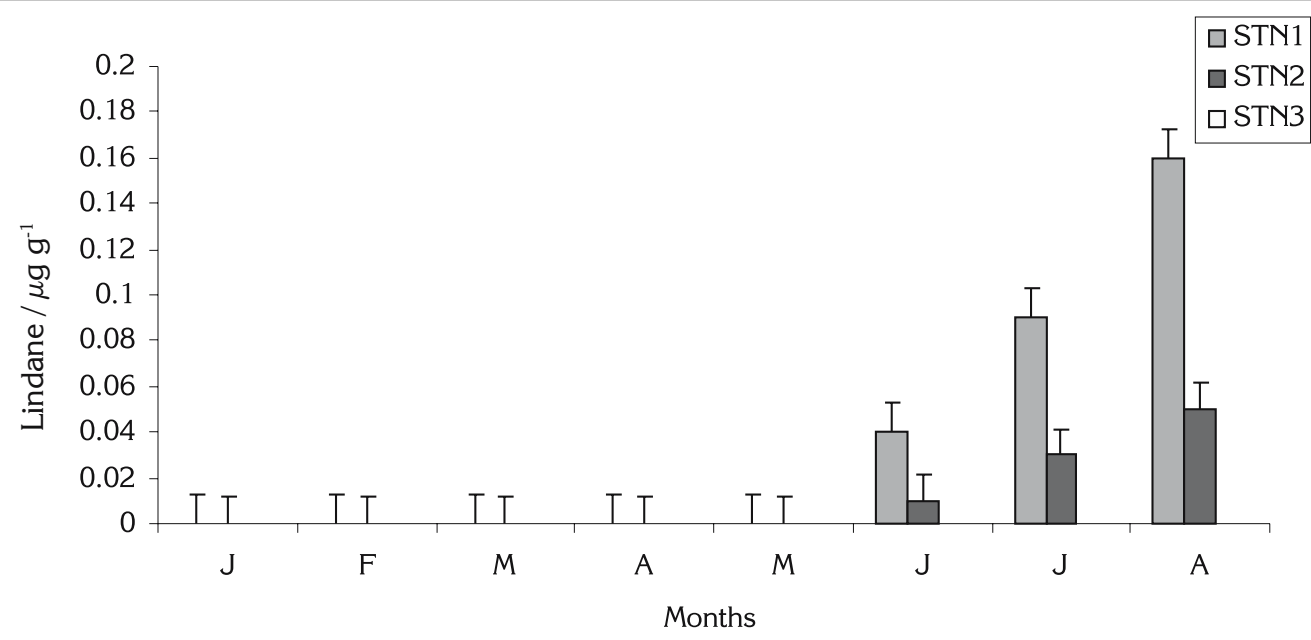

Figure 5 Lindane mass fractions $\left(\mu \mathrm{g} \mathrm{g}^{1} \mathrm{dw}\right)$ in fatty tissue of Tilapia zilli captured in the Warri River, Niger Delta, Nigeria. Data are presented as monthly mass fraction \pm standard error. 


\section{Lindane in sediment}

Tables 1 and 2 show mass fraction variations of lindane residues in the sediment samples from the Warri River. The mass fraction varied significantly both in time and space at $\mathrm{p}<0.05(\mathrm{~F}=3.13)$. The highest level of $12.66 \mu \mathrm{g} \mathrm{g}^{-1}$ dry weight (dw) was recorded at Ovwian, followed by $7.41 \mu \mathrm{g} \mathrm{g}^{-1} \mathrm{dw}$ at Ekakpamre, and $0.92 \mu \mathrm{g} \mathrm{g}^{-1} \mathrm{dw}$ at Ovu. No significant difference was found between the two seasons. The respective means for dry and wet season were $9.19 \mu \mathrm{g} \mathrm{g}^{-1} \mathrm{dw}$ and $2.29 \mu \mathrm{g} \mathrm{g}^{-1} \mathrm{dw}$ at Ovwian, $3.54 \mu \mathrm{g} \mathrm{g}^{-1} \mathrm{dw}$ and $1.28 \mu \mathrm{g} \mathrm{g}^{-1} \mathrm{dw}$ at Ekakpamre, and $0.47 \mu \mathrm{g} \mathrm{g}^{-1} \mathrm{dw}$ and $0.24 \mu \mathrm{g} \mathrm{g}^{-1} \mathrm{dw}$ (at Ovu). The extraction efficiency of surrogate standards was $99.8 \%$. The detection limit was $0.01 \mu \mathrm{g} \mathrm{g}^{-1} \mathrm{dw}$.

\section{Lindane in the tissue of Chrysichthys furcatus}

Tables 1 and 2 show that lindane mass fractions in fish tissue varied significantly both in time and space at $\mathrm{p}<0.05(\mathrm{~F}=3.13)$. The mean lindane levels were $0.59 \mu \mathrm{g} \mathrm{g}^{-1} \mathrm{dw}$ at Ovwian, $0.55 \mu \mathrm{g} \mathrm{g}^{-1} \mathrm{dw}$ at Ekakpamre, and $0.35 \mu \mathrm{g} \mathrm{g}^{-1} \mathrm{dw}$ at Ovu, while the respective means for dry and wet seasons were $2.50 \mu \mathrm{g} \mathrm{g}^{-1} \mathrm{dw}$ and $12.09 \mu \mathrm{g} \mathrm{g}^{-1} \mathrm{dw}$ at Ovwian, $0.29 \mu \mathrm{g} \mathrm{g}^{-1} \mathrm{dw}$ and $6.61 \mu \mathrm{g} \mathrm{g}^{-1} \mathrm{dw}$ at Ekakpamre, and $0.02 \mu \mathrm{g} \mathrm{g}^{-1} \mathrm{dw}$ and $0.38 \mu \mathrm{g} \mathrm{g}^{-1} \mathrm{dw}$ at Ovu. The detection limit was $0.01 \mu \mathrm{g} \mathrm{g}^{-1} \mathrm{dw}$.

\section{Lindane in the tissue of Tilapia zilli}

Tables 1 and 2 show that lindane mass fractions in Tillapia zilli varied significantly both in time and space at $\mathrm{p}<0.05(\mathrm{~F}=0.57)$. The mean values of the pesticide were $0.10 \mu \mathrm{g} \mathrm{g}^{-1} \mathrm{dw}$ at Ovwian, $0.02 \mu \mathrm{g} \mathrm{g}^{-1} \mathrm{dw}$ at Ekakpamre, and ND Ovu. The respective mean values for dry and wet seasons were $0.10 \mathrm{\mu g} \mathrm{g}^{-1} \mathrm{dw}$ and ND at Ovwian, $0.02 \mu \mathrm{g} \mathrm{g}^{-1} \mathrm{dw}$ and ND at Ekakpamre, while at the Ovu station none were detected in either season. The detection limit was $0.01 \mu \mathrm{g} \mathrm{g}^{-1} \mathrm{dw}$.

\section{DISCUSSION}

This study has found varying concentrations of lindane in surface water and mass fractions in sediment and fish (C. furcatus and $T$. zilli) samples from three stations at the Warri River. Lindane was detected in all the stations and matrices except in $T$. zilli tissue from the control station at Ovu. This points to a widespread use of lindane outside agriculture (23).
Lindane levels in sediment were much higher than in water. This confirms that sediments act as a sink for pollutants. In 2000, Castilho et al. (24) reported higher levels of pesticide compounds in the bottom sediment of a Nicaraguan River System with intensive cotton production. Similarly, Ezemonye 2005 (25) also reported higher PCB values in the sediment of the Ethiope and Benin Rivers of the Niger Delta Region, Nigeria. Higher levels of lindane detected in the fish (C. furcatus) from the Ovwian and Ekakpamre stations suggest long-term effect of agriculture and other human activities. Rand (26) reported similar results from biomonitoring pesticide residues in freshwater fish, sediment, and water the United States, and observed that the levels of pesticide compounds detected in fish tissue from eastern lowa streams and rivers were a result of long-term human activities. Lindane levels were higher in $C$. furcatus than in sediment, which suggest possible bioaccumulation and poor elimination in the fish (27). Lindane levels varied significantly between the two fish species ( $C$. furcatus and T. zilli) at $\mathrm{p}<0.05(\mathrm{~F}=4.90)$. This may be attributed to different lipid content, size, and feeding and living habits. The bottom detritus and predatory feeder $C$. furcatus had lindane residues significantly higher than the herbivorous $T$. zilli. Predatory fish might bioaccumulate pesticides by eating other fish, and the constant contact with the sediment makes them exposed to pesticides at all times. Kent and Johnson (28) found that Utah Sucker (Castomus ardens), a bottom feeder, contained the highest level of pesticide compounds in the American Fall Reservoir. Berg et al. (29) also found three to ten times higher levels of DDT in the predatory tiger fish than in zooplankton eating karpenta and red breast tilapia.

Higher lindane levels were recorded in the dry season in surface water and sediment samples, and are consistent with the observation of Osibanjo et al. (30). This may be attributed to the planting season (dry season), when farmers treat their land before planting. Most of the crops grown near Ovwian and Ekakpamre stations are seasonal, and include leafy vegetables such as the Amaranthus species, fluted pumpkin, and bitter leaf. Other crops include tomatoe, okra, sweet pepper, garden egg, and tuber crops like cassava. Low pesticide levels observed in the water and sediment during the rainy season could be the result of agricultural inactivity during this period

Pesticide levels in C. furcatus were $67 \%$ higher in the rainy season than in the dry season. This could be attributed to different living habits of the fish between 
the seasons, breaking down of the lindane in the environment, and to its absorption through the skin. According to Ernst et al. (31), accumulation of organic contaminants in the tissue of aquatic organisms depends on the physicochemical properties of the contaminant, its distribution in the aquatic system, and the feeding behaviour and metabolism of the aquatic organism.

Lindane levels seemed to increase downstream, as the Ovwian station had the highest lindane levels. The contamination at the upstream Ovu station was comparatively low, which may be due to the absence of or very low agricultural activity in the area.

\section{CONCLUSION}

This study brings the first site-specific data on lindane contamination in the Warri River of the Niger Delta. It also provides a platform for the development of regulatory measures to control further contamination of the aquatic environments in this region.

\section{REFERENCES}

1. Tetsola ED. Distribution and feeding relationship of the fishes in Warri Rivers, Nigeria. [Ph.D. Thesis]. Benin City, Nigeria: University of Benin; 1986.

2. Gabriel C. The Copepoda of Warri River. [Ph.D. Thesis]. Benin City, Nigeria: University of Benin; 1986.

3. Netherlands Engineering Company. The waters of the Western Niger Delta. The Hague: NEDECO; 1954.

4. Weinhold B. Last call for lindane. Environ Health Perspect 2001;109:A254.

5. Breivik K, Pacyna JM, Munch J. Use of alpha-beta, and gamma-hexachlorcyclohexane in Europe, 1970-1996. Sci Total Environ 1999;239:151-63.

6. Roos TC. Pharmacotherapy of ectoparasitic infections. Drugs 2001;61:1067-88.

7. Elgart ML. A risk-benefit assessment of agents in the treatment of scabies. Drug safety 1996;14:386-93.

8. Milby TH, Samuel AJ, Ottoboni F. Human exposure to lindane. Blood lindane levels as a function of exposure. J Occup Med1968;10:584-9.

9. Wauchope RD, Buttler TM, Hornsby AG, Augustijn BP, Burt JP. The SCS/ARS/CES pesticide properties database for environmental decision-making. Rev Environ Contam Toxicol 1992;123:1-155.

10. Paasivirta J. Chemical Ecotoxicology. Chelsea (MI): Lewis Publishers; 1991.
11. World Health Organization (WHO). International Program on Chemical Safety: Lindane health and safety guide. Second draft. 1989.

12. World Health Organization (WHO). Lindane. Environment health criteria 124. Geneva: WHO; 1991.

13. Reynolds JEF, editor. Martindale, the extra pharmacopoeia. $31^{\text {st }}$ ed. London: Royal Pharmaceutical Society; 1996.

14. Ullmann E, editor. Lindane. Monograph of an insecticide. Freiburg im Breisgau: Verlag K. Schillinger; 1972.

15. Schneider BA. Pesticides in surface water, distribution trends and governing factors. Pesticides in the hydrological system. Vol. 3. Chelsea: Ann Arb Press; 1979.

16. Karim AA, Haridi AA, el Rayah EA. The environmental impacts of four insecticides on non target organisms in the Gezira Irrigation Scheme canals of Sudan. J Trop Med Hyg 1985;88:161-80.

17. Kidwell JM, Philips LJ, Richard GF. Comparative analysis of contaminant levels in bottom feeding and predatory fish using the National Contaminant Biomonitoring Program Data. Bull Environ Contam Toxicol 1995;54:919-23.

18. DeLorenzo ME, Taylor LA, Lund SA, Pennington PL, Strozier ED, Fulton $M H$. Toxicity and bioconcentration potential of the agricultural pesticide endosulfan in phytoplankton and zooplankton. Arch Environ Contam Toxicol 2002;42:173-81.

19. Waliszewski SM, Aguirre AA, Infanzon RM, Siliceo J. Carry-over of persistent organochlorine pesticides through placenta to fetus. Salud Publica Mex 2000;42:384-90.

20. Edwards $C A$. The environmental impact of pesticides. Parasitis 1987;86:309-29.

21. World Wildlife Fund. Hazards and exposures associated with DDT and synthetic pyrethroids used for vector control. Washington (DC): World Wildlife Fund; 1999.

22. Steinwandter H. Contributions to the on-line method for the extraction and isolating of pesticide residues and environmental chemicals II. Miniaturization of the on-line method. Fresenius J Anal Chem 1990;336:811.

23. Leonard AW, Hyne RP, Lim KA, Leight KC. Fate and toxicity of pesticide in Namoi river water and bottom sediment. J Environ Qual 2001;30:750-9.

24. Castilho JA, Fenzl N, Guillen SM, Nascimento FS. Organochlorine and organophosphate pesticide residues in the Atoya river basin, Chinandega, Nicaragua. Environ Pollut 2000;110:523-35.

25. Ezemonye LIN. Polychlorinated biphenyls (PCBs) levels and distribution in Ethiope and Benin Rivers of the Niger Delta, Nigeria: surface water and sediments. Int J Environ Studies 2005;62:491-504. 
26. Rand GM, editor. Fundamental of Aquatic Toxicology: Effects, Environmental Fate and Risk Assessment. $2^{\text {nd }}$ ed. Washington (DC): Taylor and Francis; 1990.

27. Wilfred QB, von Düszeln J. Analysis of pesticides in Costa Rica with special emphasis on water and fish samples. Technical Report. Bremen: Deutsche Gesellschaft für Technische Zusammenarbeit; 1995.

28. Kent JC, Johnson DW. Organochlorine residues in fish, water and sediment of American Falls Reservoir, Idaho. Pest Monit J 1974;13:28-34.

29. Berg H, Kilbus M, Kautsky N. DDT and other insecticides in the Lake Kariba ecosystem, Zimbabwe. Ambio 1992;21:444-50.
30. Osibanjo O, Biney O, Calamari D, Kaba N, Mbome IL, Naeve H, Ochumba PBO, Saad MAH. Chlorinated hydrocarbon substances. In: David C, editor. Review of pollutants in the African aquatic environment. CIFA Tech. Paper no. 25. Rome: FAO; 1994. p. 61-91.

31. Ernst WR, Jonah P, Doe K, Julien G, Hennigar P. Toxicity to aquatic organisms of off- target deposition of endosulfan applied by aircraft. Environ Toxicol Chem 1991;10:103-14. 


\section{Sažetak}

RASPODJELA LINDANA U VODI, SEDIMENTU I RIBAMA IZ RIJEKE WARRI (DELTA NIGERA, NIGERIJA)

Istražene su pojava i raspodjela lindana u površinskoj vodi, sedimentu i dvije vrste riba Chrysichthys furcatus i Tilapia zilli iz rijeke Warri u zapadnom dijelu delte Nigera (Nigerija). Uzorci su skupljeni 2006. godine na tri postaje (Ovwian, Ekakpamre i Ovu) tijekom sušne (siječanj - travanj) i vlažne sezone (svibanj - kolovoz). Analizirano je ukupno 96 uzoraka: po 24 uzorka vode, sedimenta i riba. Razine pesticida određene su primjenom tekućinske kromatografije visoke djelotvornosti (HPLC) te je utvrđivana njihova raspodjela u različitim dijelovima okoliša. Koncentracije rezidua u uzorcima vode bile su u rasponu: ispod granice detekcije (BDL) do 1,37 $\mu \mathrm{g} \mathrm{L}^{-1}$, u sedimentu: BDL do 12,66 $\mu \mathrm{g} \mathrm{g}^{-1}$ suhe tvari, u ribama Chrysichthys furcatus: BDL do 16,67 $\mu \mathrm{g} \mathrm{g}^{-1}$ suhe tvari te Tilapia zilli: BDL do 0,15 $\mu \mathrm{g} \mathrm{g}^{-1}$ suhe tvari. Određene vrijednosti bile su ispod graničnih vrijednosti $\left(0,01 \mu \mathrm{g} \mathrm{L}^{-1}\right)$ propisanih od Nigerijske uprave za zaštitu okoliša i Europske unije. Kako su dobivene vrijednosti bile relativno više u odnosu na podatke iz ranijih istraživanja okoliša u Nigeriji, istaknuta je potreba trajnog monitoringa vodotoka u delti Nigera.

KLJUČNE RIJEČI: bioakumuliranje, Chrysichthys furcatus, granične vrijednosti, Tilapia zilli

\section{CORRESPONDING AUTHOR:}

Lawrence Ikechukwu Ezemonye

Department of Animal and Environmental Biology (AEB)

University of Benin, Benin City, Nigeria

E-mail:ezemslaw@yahoo.com 